\section{HENRY EDWARD ARMSTRONG}

Henry Edward Armstrong

Educational Work. By Charles E. Browne. Pp. xiii $+26+4$ plates. (London: Christ's Hospital, 26 Great Tower Street, E.C.3, 1954.) $6 s$.

$\mathrm{HE}$ title of this book is too comprehensive for

the restricted scope of its contents. A volume so slender can tell us little about its subject and less about his extensive educational work. 'H. E. A.', a man of remarkable personality, great vitality and vigour of mind, a prophet and a visionary, besides being a deep and versatile scholar of critical outlook and independence of thought, was a prolific writer and forceful speaker and had a rare gift of expression. Conscious of a mission and burning with the fiery zeal of reform, he marshalled his great gifts and directed his efforts towards improving science toaching in the schools of Britain, and arousing and educating the public to a realization of the everincreasing influence of science in human affairs.

A fearless advocate of the causes he had at heart, he was an indefatigable educator and reformer. His weapon was the strength of his arguments, clearly and persistently put forward; his weakness, his use of biting wit and bitter comment. For he made little use of patient persuasion and delighted in stinging his audience. He admitted the unpleasantness of his methods, necessary, he maintained, to arouse people out of their apathy and indifference and make them think. Supineness and complacency, whether in a community or a person in authority, roused his wrath. He was the stormy petrel of every committee on which he sat, the terror of editors of scientific journals, and the critic of everyone straying from the path of the scientific method.

By his articles and letters to the Press, Armstrong attempted to educate the public on scientific matters. $\mathrm{He}$ exhorted farmers to study the cultivation of sweet grass and repeatedly pointed out the health value of pure milk and wholesome bread. Ahead of his time, he urged that the scientific method should be applied to the exploitation of the Coal Measures of Britain. Again, he brought forward strong arguments for making a survey of the world's resources. His edifying addresses to professional chemistscritical, hortatory and inspiring-are as pertinent to-day as when they were written. Many pupils who owed their chemical education to him later became distinguished university professors. The booklet under review has of necessity little mention, not to speak of expansion, of the above educational activities.

From the storm and turmoil of heated controversy, Armstrong seems to have found a psychological rest in his service to Christ's Hospital. He was a governor of this old and richly endowed London school for more than forty years, and was influential in getting it removed to Horsham in Sussex. There, amid ideal surroundings, with spacious well-equipped laboratories, very small classes and a specially selected staff, all due to his initiative and drive, he was able to get science taught in a way dear to his heart. The boys were trained in the art and method of discovery, and learned only what could be argued from experiments carried out by themselves, a method of teaching later called 'heurism'. Most of the text and all the illustrations of the booklet are concerned with this phase of Armstrong's educational work. Sir William Hamilton Fyfe, headmaster in
Armstrong's day, contributes the charming and laudatory prologue; in the epilogue, Dr. G. van Praagh, the present senior science master, in summing up the "Heuristic Method To-day", has nothing to add to what is already known. The author, the chief member of the science team collected by Armstrong, pays a pious tribute to his old master, and is warmly appreciative of the work he did for Christ's Hospital. The book should delight the 'Old Blues' who came under the influence of 'H. E. A.', and should help to keep fresh the memory of one who did his utmost to urge scientists to make ceaseless effort.

G. Fowles

\section{THE INTERACTION OF SCIENCE AND SOCIETY}

Science in History

By Prof. J. D. Bernal. Pp. xxiv +967 . (London : C. A. Watts and Co., Ltd., 1954.) 42s. net.

TEITHER of the two terms occurring in the title of this volume must be taken in the strict sense tradition attributes to them, in which science means natural seience only and history is exclusively related to the irrevocable past. Science here covers social sciences as well, and the history that is told extends to the date of publication of the book.

One need not read far to become aware of the motives prompting the author to take this broad and comprehensive view of his subject. It was not his intention to deal with history for history's s\&ke, but as a means of understanding the interaction of science and society, the importance of which is so conspicuous in these days and will surely become still clearer in the future. Accordingly, the historical approach plays the part of an introduction, and the author's aims would have been wholly thwarted if he had stopped short at the end of the nineteenth century, where as a rule works on the history of science have their time limit.

There is another thing which is clear to the reader from the very beginning of the book, namely, that the author considers the vicissitudes of science in the past and present from a deliberately Marxist point of view. $\mathrm{He}$ is convinced that not only the means used by scientists in their researches but also the guiding ideas of their theoretical approach are conditioned by the events and pressures of society; that scientific problems are set in the first place by actual economic necessity, and only in the second place do they arise out of earlier scientific ideas; that a new economic system inevitably involves a different experimental science; that history has to be interpreted in terms of economics only and that consequently science in each period of its development has to be treated as a social and economic phenomenon.

In my opinion, this way of looking at the history of science means that an undoubtedly important aspect of development, namely, the indisputable relations between science and society, is unnecessarily made absolute, and raised to a status of uniqueness, with the neglect of numerous other equally important influences. Nevertheless; I must acknowledge the excellent manner in which the author acquits himself of the task he undertook. His mastery of the most diverse subjects in the history of science and in its present phase deserves the highest admiration. The way in which he expounds his views is perfectly clear. As he avows 